Journal of Animal and Veterinary Advances 9 (3): 604-609, 2010

ISSN: $1680-5593$

(C) Medwell Journals, 2010

\title{
Effect of Probiotic Bacteria on Immunoglobulin G Concentration and Other Blood Components of Newborn Calves
}

\author{
M.Y. Al-Saiady \\ Department of Animal Production, College of Food Science and Agriculture, \\ King Saud University, P.O. Box 2460, Riyadh 11451, Saudi Arabia
}

\begin{abstract}
Twenty-four, 3-4 days old male calves were used in this study. All animals were clinically normal. They were weighed within $24 \mathrm{~h}$ of arrival and divided into 3 groups A-C matched for body weight. Group A (control) calves were given a basal diet containing a combination of whole pasteurized milk and reconstituted milk replacer. In group B, a commercial culture of L. acidophilus and L. plantarum was added to the basal diet. In group $\mathrm{C}$ a culture of L. acidophilus $27 \mathrm{sc}$ was added to the basal diet. Serum total proteins, albumin and total globulins were comparable in all three groups as were the serum concentrations of urea, BUN and triglycerides. Serum inorganic constituents also showed no significant differences between the control and treated groups. A significant increase in serum Ig G concentration was recorded in the probiotic-supplemented groups, which also showed a significant increase in body weight at 5 weeks and during the entire experimental period.
\end{abstract}

Key words: Probiotic, L. acidophilus, L. plantarum, hematology, serum lg G, serum total proteins

\section{INTRODUCTION}

Neonatal diarrhea is a major cause of calf mortality worldwide. Its morbidity in individual herds can be as high as $80 \%$ (Cornaglia et al., 1992; Wright et al., 1995), while its mortality ranges between 1.5 and $8 \%$ (Bendali et al., 1999; NAHMS, 2007). According to Davis and Drackley (1998) and NAHMS (2007) gastrointestinal infections and subsequent diarrhea and dehydration account for the majority of health problems affecting calves during the pre-weaning period and are the primary reason for poor development and death in the first 60 days of age.

Treatment of calf diarrhea is commonly based on broad-spectrum antibiotics or other antimicrobials agents. In addition to preventing infection by pathogenic bacteria in newborn calves, antibiotics have also been used as growth promoters in livestock. However, the frequent use of antibiotics in livestock can have serious consequences such as the development of resistant populations of bacteria. Subsequent use of the same antibiotics for therapy might therefore be ineffective. Also, residual antibiotics in dairy foods, meat, eggs and milk are unacceptable. Probiotic treatment is currently attracting increasing attention as a means of reducing the risk of infection, while enhancing the immune system in livestock (Abe et al., 1995; Avita et al., 1995; Kyriakis et al., 1999). A probiotic is defined as a live microbial feed supplement, which beneficially affects the host animal by improving its intestinal microbial balance (Fuller, 1989). Some species of Lactic Acid Bacteria (LAB) have been claimed as probiotics, such as Lactobacillus acidophilus, L. delbrueckii sub sp. bulgaricus, L. casei, L. fermentum, L. plantarum and L. reuteri.

To be considered as probiotics, these bacteria should become part of the normal microbial flora in the intestine, survive the gastrointestinal passage and be able to adhere and colonize the intestinal tract (Havenaar et al., 1992). Previous studies have demonstrated the importance of LAB to human and animal health (Bengmark, 1998; Fuller, 1989; Goldin and Gorbach, 1980). Some types of $\mathrm{LAB}$ can affect protective immunity against pathogens and tumors and have the ability to increase the mucosal immune response (Goldin and Gorbach, 1980; Isolauri et al., 1994; Kimura et al., 1997; Majamaa et al., 1995). Antimicrobial activity is thought to be an important means by which probiotic bacteria competitively exclude or inhibit the activities of harmful intestinal microbes. Antimicrobial compounds produced by probiotic bacteria include organic acids (lactic and acetic acid), hydrogen peroxide (in environments where abundant oxygen is present), $\beta$-hydroxypropionaldehyde (produced by $L$. reuteri) as well as bactericidal or bacteriostatic peptides and proteins (De Vuyst and Vandamme, 1994). Donovan et al. (2002) reported that growth and performance of calves receiving probiotics are equivalent to those of calves fed antibiotics during the first 5 weeks of age. Direct-Fed Microbial (DFM) products used in 
calves provide benefits by several mechanisms, e.g., restricting adherence of pathogenic microbes to mucosal surfaces (La Ragione et al., 2001), stimulating immune responses (Hong et al., 2005) and proliferation of other beneficial microorganisms (Abe et al., 1995) and producing antimicrobial substances (Hong et al., 2005). The objective of the present study was to investigate the effect of probiotics on neonatal calf health as reflected in their blood cellular, biochemical and chemical constituents and IgG levels.

\section{MATERIALS AND METHODS}

Twenty four, clinically normal 3-4 days old, Holstein male calves were purchased from a commercial dairy farm in Riyadh (central province-Saudi Arabia). The calves were weighed within $24 \mathrm{~h}$ of arrival and divided into 3 groups, A-C matched for Body Weight (BW). They were placed individually in cool, well-ventilated houses.

Group A (Control) calves were given a basal diet containing a combination of whole pasteurized milk and reconstituted milk replacer. The latter contained $24 \%$ protein, $19 \%$ fat, $10 \%$ mineral, $5 \%$ crude fiber and $42.5 \%$ carbohydrate (United Company, Saudi Arabia). The diet was non-medicated and was reconstituted in $13 \%$ dry matter. For group B, commercial culture of L. acidophilus and L. plantarum (Bio Saver, Kemin Industries Inc. Des Moines, IA, USA) was added to the basal diet at manufacturer's recommended amounts $(1.25 \mathrm{~g} / 100 \mathrm{~kg}$ of milk). For group $\mathrm{C}$ a culture of L. acidophilus $27 \mathrm{sc}$ (obtained form the Animal Science Department of Oklahoma State University, OK, USA and propagated in our laboratories) was added to the basal diet prior to feeding at concentration of $1.85 \times 10^{7}$ colony forming Unit/liter Cfu 1-1). All calves received liquid diet at $8 \%$ of initial BW twice daily with maximum of $2 \mathrm{~kg} /$ feeding for 9 weeks and were restricted to $1.25 \mathrm{~kg} /$ feeding during 10 weeks and then weaned.

The calves were offered pelleted starter feed adlibitum consisting of $17 \%$ crude protein, $15.4 \%$ digestible protein, $2 \%$ ether extract, $8.5 \%$ crude fiber, $0.8 \%$ $\mathrm{Ca}, 0.45 \% \mathrm{P}$ and $0.85 \% \mathrm{NaCl}$ on dry matter (Grain silo and flour mill organization-Saudi Arabia). A $0.20 \mathrm{~kg}$ chopped alfalfa hay containing $91.06 \% \mathrm{DM}$ (19.63\% crude protein, $1.75 \%$ ether extract, $30.29 \%$ acid detergent fiber, $1.4 \% \mathrm{Ca}$ ) and $0.22 \% \mathrm{P}$ was also fed ad libitum.

The animals were allowed free access to water and were weighed individually every 2 weeks. Two $10 \mathrm{~mL}$ blood samples were obtained from each calf by jugular venipuncture using EDTA-K and plain vacutainers (Becton, Dickinson and Co., USA) for hematological and serum analyses, respectively. These samples were collected 1 week before treatment and at 2 week intervals thereafter for a total of 15 weeks HemogloBin $(\mathrm{Hb})$ was determined by a cyanomethoglobin method, Packed Cell Volume (PCV) by hematocrit centrifuge and white Blood Cell Count (WBCs) by hemocytometer. The sera were separated by centrifugation at $1500 \mathrm{~g}$ from clotted blood samples, dispensed into vials and stored at $-20^{\circ} \mathrm{C}$ until used.

Total serum Protein (TP) concentration was determined by Biuret method (Henry, 1974), Albumin (ALB) by bromocresol green method (Rodkey, 1965) and total Globulin (GLOB) as the difference between TP and ALB. The albumin/globulin ratio was calculated. Total cholesterol, glucose, total lipids, triglycerides and urea concentration were determined Spectrophotometercally (Dr. Lang-LP3-West Germany) using commercial reagent kits (Randox Laboratories Ltd-Diamond Road-UK). Blood Urea Nitrogen (BUN) was calculated from urea. Inorganic serum constituent were determined using an atomic absorption spectrophotometer (Perkin-Elmer Ltd, UK). For $\mathrm{Fe}$ and $\mathrm{Zn}$ determination the serum was diluted 5 folds in demineralized water; for $\mathrm{Mg}, \mathrm{Ca}$ and $\mathrm{K} 50$ folds and for $\mathrm{Na}$ 500 folds in 0.25 strontium chloride. Immunoglobulin $\mathrm{G}$ (IgG) was determined by indirect sandwich Elisa method using commercial kits (Immunological and biochemical test system Gmbh-west Germany).

Statistical analysis: The data were subjected to statistical analysis using the SAS program (SAS, 2000). The GLM and least-Square means (LSmeans) were applied to the data.The effect of treatment on animal's health and blood parameters was tested using the following model:

Where:

$$
\mathrm{Y}_{\mathrm{ij}}=\mu+\mathrm{T}_{\mathrm{j}}+\mathrm{e}_{\mathrm{ij}}
$$

$Y_{i j}=$ The ith observation of the jth treatment

$\mu=$ The population mean

$\mathrm{T}_{\mathrm{j}}=\operatorname{Treatment}(\mathrm{j}=1-3)$

$\mathrm{e}_{\mathrm{ij}}=$ The residual error

\section{RESULTS AND DISCUSSION}

Blood hematology, biochemistry and serum inorganic: The results are summarized in Table 1 and 2. Both probiotic treated groups had higher $\mathrm{Hb}$ and $\mathrm{PCV}$ values than the control although the difference was significantly significant only in group $\mathrm{C}$ calves. To the knowledge, there are no previous studies on the effect of probiotic supplementation on the hematology of calves. However, increased hemoglobin concentration, RBC and PCV were previously reported in kids (Sayed, 2003) and Turkeys 
Table 1: Effect of treatment on Means + SE for blood hematology and biochemistry

\begin{tabular}{|c|c|c|c|c|}
\hline Parameters & $\mathrm{A}(\mathrm{N}: 8)$ & $\mathrm{B}(\mathrm{N}: 8)$ & $\mathrm{C}(\mathrm{N}: 8)$ & Initial mean value* (N:24) \\
\hline $\mathrm{TP} \mathrm{gL}^{-1}$ & $51.68 \pm 0.70$ & $53.69 \pm 0.77$ & $51.72 \pm 0.77$ & $55.78 \pm 1.59$ \\
\hline $\mathrm{AL} \mathrm{g} \mathrm{L}{ }^{-1}$ & $31.33 \pm 0.27^{b}$ & $32.39 \pm 0.27^{\mathrm{a}}$ & $32.92 \pm 0.27^{\mathrm{a}}$ & $33.61 \pm 0.40^{\mathrm{a}}$ \\
\hline $\mathrm{GL} \mathrm{g} \mathrm{L}^{-1}$ & $20.35 \pm 0.70^{\mathrm{ab}}$ & $21.31 \pm 0.70^{\mathrm{a}}$ & $18.75 \pm 0.70^{b}$ & $22.51 \pm 1.80^{\mathrm{a}}$ \\
\hline UR mmol L ${ }^{-1}$ & $4.42 \pm 0.12^{b}$ & $4.72 \pm 0.12^{\mathrm{ab}}$ & $4.80 \pm 0.12^{\mathrm{a}}$ & $8.24 \pm 0.12^{c}$ \\
\hline BUN mmol L-1 & $2.06 \pm 0.05^{b}$ & $2.21 \pm 0.05^{\mathrm{ab}}$ & $2.24 \pm 0.05^{\mathrm{a}}$ & $3.85 \pm 0.05^{\mathrm{c}}$ \\
\hline TLI mmol L ${ }^{-1}$ & $4.84 \pm 0.12^{\mathrm{a}}$ & $4.13 \pm 0.12^{b}$ & $4.46 \pm 0.12^{b}$ & $5.27 \pm 0.12^{c}$ \\
\hline CHLO mmol L-1 & $3.07 \pm 0.08^{\mathrm{a}}$ & $2.67 \pm 0.08^{b}$ & $2.80 \pm 0.08^{b}$ & $2.04 \pm 0.07^{b}$ \\
\hline TRI mmol L ${ }^{-1}$ & $0.36 \pm 0.03^{b}$ & $0.37 \pm 0.03^{b}$ & $0.41 \pm 0.03^{b}$ & $0.46 \pm 0.04^{\mathrm{a}}$ \\
\hline GLU mmol L $\mathrm{L}^{-1}$ & $0.91 \pm 0.08^{\mathrm{a}}$ & $0.58 \pm 0.08^{b}$ & $0.69 \pm 0.08^{b}$ & $1.12 \pm 0.26^{\mathrm{a}}$ \\
\hline PCV\% & $30.98 \pm 0.66^{b}$ & $32.98 \pm 0.66^{b}$ & $34.73 \pm 0.66^{\mathrm{a}}$ & $29.38 \pm 0.66^{c}$ \\
\hline $\mathrm{HB} \mathrm{mg} \mathrm{dc}^{-1}$ & $9.49 \pm 0.20^{b}$ & $9.96 \pm 0.20^{\mathrm{ab}}$ & $10.43 \pm 0.20^{\mathrm{a}}$ & $9.27 \pm 0.21^{\mathrm{b}}$ \\
\hline WBC $\times 10^{9} \mathrm{~L}^{-1}$ & $6.87 \pm 0.31^{\mathrm{b}}$ & $7.55 \pm 0.31^{\mathrm{a}}$ & $7.80 \pm 0.31^{\mathrm{a}}$ & $6.57 \pm 0.31^{\mathrm{b}}$ \\
\hline $\mathrm{A} / \mathrm{G}$ & $1.69 \pm 0.07^{\mathrm{b}}$ & $1.65 \pm 0.07^{b}$ & $1.94 \pm 0.07^{\mathrm{a}}$ & $1.80 \pm 0.07^{\mathrm{a}}$ \\
\hline IgG ng mL $\mathrm{m}^{-1}$ & $159.51 \pm 51.0^{b}$ & $259.89 \pm 5.72^{\mathrm{a}}$ & $273.49 \pm 6.36^{\mathrm{a}}$ & $247.53 \pm 7.81^{\mathrm{a}}$ \\
\hline
\end{tabular}

Different letters within row mean significant difference $(\mathrm{p}<0.01)$; $\mathrm{TP}=$ Total Protein, $\mathrm{AL}=$ Albumen, $\mathrm{GL}=$ Globulin, UR $=$ Urea, BUN $=\mathrm{Blood}$ Urea

Nitrogen, TLI = Total Lipids, CHLO = Cholesterol, TRI = Triglyceride, GLU = Glucose, $\mathrm{PCV}=$ Packed Cell Volume, HB $=$ Hemoglobin, WBC $=$ White

Blood Corpuscle, $\mathrm{A} / \mathrm{G}=$ Albumen/Globulin; *Initial mean values determined 1 week prior to treatment

Table 2: Treatment effect on Means+SE of blood electrolytes

\begin{tabular}{lrrrr}
\hline Parameters & A (No:8) & B (No:8) & C (No:8) & Initialmean value* (No:24) \\
\hline K mmol L & $5.08 \pm 0.14^{\mathrm{b}}$ & $5.40 \pm 0.14^{\mathrm{b}}$ & $4.78 \pm 0.14^{\mathrm{c}}$ & $6.21 \pm 0.14^{\mathrm{a}}$ \\
$\mathrm{NA} \mathrm{mmol} \mathrm{L}$ & $136.66 \pm 2.90$ & $135.50 \pm 2.90$ & $137.53 \pm 2.90$ \\
$\mathrm{CA} \mathrm{mmol} \mathrm{L}^{-1}$ & $134.44 \pm 2.94$ & $3.47 \pm 0.18^{\mathrm{ab}}$ & $3.28 \pm 0.18^{\mathrm{b}}$ & $3.80 \pm 0.18^{\mathrm{ab}}$ \\
$\mathrm{MG} \mathrm{mmol} \mathrm{L}^{-1}$ & $3.92 \pm 0.18^{\mathrm{a}}$ & $0.63 \pm 0.03^{\mathrm{b}}$ & $0.62 \pm 0.03^{\mathrm{b}}$ & $0.84 \pm 0.06^{\mathrm{a}}$ \\
ZN umol L & $0.58 \pm 0.03^{\mathrm{b}}$ & $17.04 \pm 0.39^{\mathrm{b}}$ & $18.30 \pm 0.39^{\mathrm{a}}$ & $17.24 \pm 0.39^{\mathrm{b}}$ \\
$\mathrm{CU} \mathrm{umol} \mathrm{L}^{-1}$ & $16.85 \pm 0.39^{\mathrm{b}}$ & $9.48 \pm 0.33^{\mathrm{a}}$ & $7.95 \pm 0.33^{\mathrm{b}}$ & $10.19 \pm 0.34^{\mathrm{a}}$ \\
FE mg L & $8.43 \pm 0.33^{\mathrm{b}}$ & $56.57 \pm 2.54^{\mathrm{b}}$ & $66.79 \pm 2.54^{\mathrm{a}}$ & $64.23 \pm 2.48^{\mathrm{a}}$ \\
\hline
\end{tabular}

Different letters within row mean significant difference $(p<0.01)$; * Initial mean values determined one week prior to treatment

(Cetin et al., 2005) supplemented with probiotic. A significantly higher WBC count was also recorded in the study in calves of groups $\mathrm{B}$ and $\mathrm{C}$ compared to the controls.

A similar increase in WBC count was reported in birds given probiotic-supplemented diets (Rahimi and Khaksefidi, 2006). Furthermore, CHLO and TLI values were significantly reduced in the calves of groups B and $\mathrm{C}$ receiving probiotic supplement in comparison to control. This phenomenon is widely documented in the literature both in animals and humans (Mohan et al., 1990; Zacconi et al., 1992; Agerholmlarsen et al., 2000; Liong and Shah, 2005; Salma et al., 2007; Vasiljevic and Shah, 2008; Bakr et al., 2009; Ataie-Jafari et al., 2009; Ignatova et al., 2009). Serum proteins (TP, ALB and GLOB) were comparable in all three groups (A-C) as were the serum concentrations of urea, BUN and triglycerides.

On the other hand, serum inorganic constituents did not show a definite trend and no significant differences were recorded between the control and treated groups with regards to $\mathrm{K}, \mathrm{Na}$ and $\mathrm{Mg}$ levels.

Slight but significant increases in $\mathrm{Zn}$ and $\mathrm{Cu}$ and decreases in $\mathrm{Fe}$ and $\mathrm{Ca}$ levels were recorded in groups $\mathrm{B}$ and $C$, respectively, although their values were still within normal ranges for calves. A significant finding in the study is the marked increase in serum Ig G concentration in the probiotic-supplemented groups, particularly group $\mathrm{C}$ (259.9 and $273.5 \mathrm{ng} \mathrm{mL}^{-1}$, for groups B and C) calves versus the controls (159.5 ng $\mathrm{mL}^{-1}$ ). Probiotic Lactobacillus has also been reported to stimulate mucosal immunity and augment the production of secretory antibodies (IgA) in humans and animals (Kimura et al., 1997; Perdigon et al., 1999).

Recent studies have also shown that probiotic therapy in critically ill patients with multiple organ dysfunction syndrome greatly enhanced their immune activity with significant increases in Ig A and Ig $\mathrm{G}$ antibodies and reduced incidence of diarrhea in comparison to placebo-controls (Alberda et al., 2007). A significant increase in serum Ig $\mathrm{G}$ concentration was also reported in adult healthy dogs receiving $L$. acidophilus supplement indicating that this probiotic bacterium might enhance the health and immune functions of these animals (Bailon et al., 2004).

Similarly, administration of probiotic bacteria in chickens was shown to enhance specific, systemic antibody response and to stimulate the production of natural antibodies such as serum Ig G and Ig M (Haghighi et al., 2006). Previous studies have indicated that the modulation of innate and adaptive immunity by probiotics is a dose and strain-dependent phenomenon (Perdigon et al., 1999, 2002; Galdeano and Perdigon, 2004; Alberda et al., 2007). 


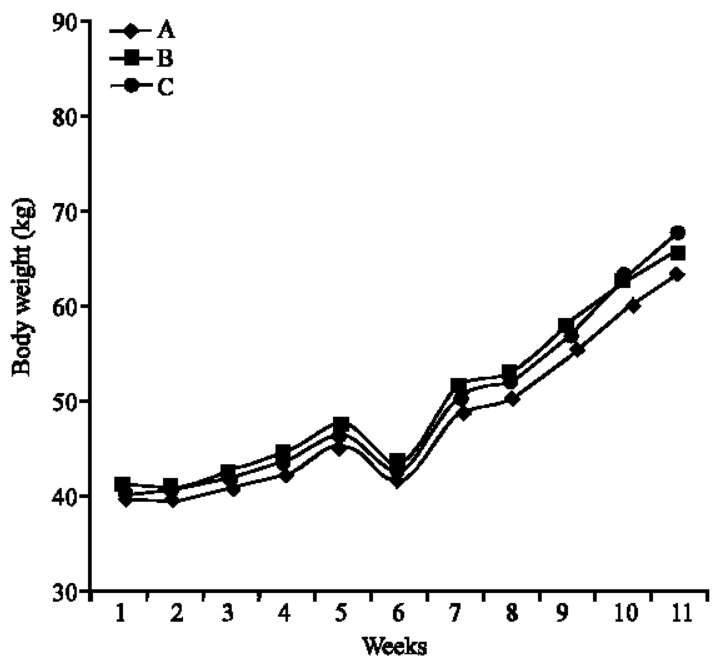

Fig 1: Effect of treatment on Mean+SE body weights of probiotic-fed versus control calves

Body weight gain: Mean bodyweight of the calves prior to probiotic treatment was $46.6+0.68 \mathrm{~kg}$ (range $45.50-47.56 \mathrm{~kg}$ ). Both probiotic treated groups (B and C) gained more weight $(\mathrm{p}<0.05)$ during the experiment than the control group (Fig. 1) indicating that probiotic treatment using L. acidophilus or a combination of L. acidophilus and L. plantarum, particularly the latter was beneficial to the growth of these animals. At the conclusion of the experiment, the mean body weight gain in groups $\mathrm{B}$ and $\mathrm{C}$ was $41.75+1.25$ and $37.25+1.25$, respectively versus $35.63+1.25$ in the controls. These findings are consistent with the previous studies (Abu-Tarboush et al., 1996) and those of many other investigators (Abe et al., 1995; Ghorbani et al., 2002; Krehbiel et al., 2003; Isk et al., 2004; Timmerman et al., 2005; Bakr et al., 2009). Further studies should however, be undertaken to investigate this aspect and other beneficial effects of probiotics in growing calves and to determine optimal probiotic bacterial strains and doses to enhance performance and health in these animals.

\section{CONCLUSION}

The increase in bodyweight, serum Ig G concentration, $\mathrm{Hb}$ and $\mathrm{PCV}$ and the decrease in $\mathrm{CHO}$ and TLI presently recorded in calves receiving probiotic supplementation are all signs of improved health indicating the potential benefits of Lactobacillus bacteria. Further studies concerning beneficial effects of probiotics in growing calves should be pursued using different doses and strains of probiotic bacteria.

\section{ACKNOWLEDGEMENTS}

The researcher is grateful to thanks Mansour F. Hussein for his critical revision and editing of this manuscript. Also special thanks extended to Mr. A. Gar Elnabi and the staff in his Laboratory at Animal Production Department, K.S.U for the analysis of blood samples. special thank are due to Dr. H. H. Mogawer for his technical and statistical support.

\section{REFERENCES}

Abe, F., N. Ishibashi and S. Shimamura, 1995. Effect of administration of Bifidobacteria and lactic acid bacteria to newborn calves and piglets. J. Dairy Sci., 78: 2838-2846.

Abu-Tarboush, H.M., M.Y. Al-Saiady and A.H. Keir El-Din, 1996. Evaluation of diet contaning lactobacili on performance, fecal coliform and lactobacilli of young dairy calves. J. Anim. Feed Sci. Technol., 57: 39-49.

Agerholmlarsen, L., A. Raben, N. Haulrlk, A. Hansen, M. Manders and A. Astrup, 2000. Effect of 8 weeks intake of probiotics milk products on risk factors for cardiovascular diseases. Eur. J. Clin. Nutr., 54: 288-297.

Alberda, C., L. Gramlich, J. Meddings, C. Field and L. McCargar et al., 2007. Effects of probiotic therapy in critically ill patients: A randomized double-blind, placebo-controlled trial. Am. J. Clin. Nutr., 85: 816-823.

Ataie-Jafari, A., B. Larijani, H.A. Majd and F. Tahbaz, 2009. Cholesterol-lowering effect of probiotic yogurt in comparison with ordinary yogurt in mildly to moderately hypercholester-olemic subjects. Ann. Nutr. Meta., 54: 22-27.

Avita, F.A., A.C. Paulillo, R.P. Schocken-Iturrino, F.A. Lucas, A. Orgaz and J.L. Quintana, 1995. A comparative study of the efficiency of a probiotic and the anti-K99 and anti-A14 vaccines in the control of diarrhea in calves in Brazil. Rev. Elev. Med. Vet. Pays Trop., 48: 239-243.

Bailon, M.A., Z.V. Marshall-Jones and R.F. Butterwick, 2004. Effect of probiotic Lactobacillus acidophilus strain DSM1 3241 in healthy adult dogs. Am. J. Vet. Res., 65: 338-343.

Bakr, H.A., E.M. Said, M.M.A. El-Tawab, M.S. and M.S. Hassan, 2009. The impact of probiotic (Biovet $($ ) on some clinical, hematological and biochemical parameters in buffalo-calves. Vet. Med. J., 19: 1-10.

Bendali, F., H. Bichet, F. Schelcher and M. Sanaa, 1999. Pattern of diarrhea in newborn beef calves in southwest France. Vet. Res., 30: 61-74. 
Bengmark, S., 1998. Ecological control of the gastrointestinal tract: The role of probiotic flora. Gut, 42: 2-7.

Cetin, N., B.K. Guclu and E. Cetin, 2005. The effect of probiotic and mannanoligo-saccharide on some haematological and immunological parameters in turkeys. J. Vet. Med., 52: 263-267.

Cornaglia, E.M., F.M. Fernandez, M. Gottschalk, M.E. Barrandeguy and A. Luchelli et al., 1992. Reduction in morbidity due to diarrhea in nursing beef calves by use of an inactivated oil-adjuvanted rotavirus-Escherichia coli vaccine in the dam. Vet. Microb., 30: 191-202.

Davis, C.L. and J.K. Drackley, 1998. The Development, Nutrition and Management of the Young Calf. Iowa State Press, Ames.

De Vuyst, L. and E.J. Vandamme, 1994. Antimicrobial Potential of Lactic Acid Bacteria. In: Bacteriocins of Lactic AcidBacteria, De Vuyst, L. and E.L. Vandamme (Eds.). Blackie Academic and Professional, Glasgow, United Kingdom, pp: 91-142.

Donovan, D.C., S.T. Franklin, C.C.L. Chase and A.R. Hippen, 2002. Growth and health of Holstein calves fed milk replacers supplemented with antibiotics or enteroguard. J. Dairy Sci., 85: 947-950.

Fuller, R., 1989. Probiotics in man and animals: A review. J. Applied Bacteriol., 66: 365-378.

Galdeano, C. and G. Perdigon, 2004. Role of viability of probiotic strains in their persistence in the gut and in mucosal immune stimulation. J. Applied Microb., 97: 673-681.

Ghorbani, G.R., D.P. Morgavi, K.A. Beauchemin and J.A. Leedle, 2002. Effect of bacterial direct-fed microbial on ruminal fermentation, blood variables and the microbial population of feedlot cattle. J. Anim. Sci., 80: 1977-1985.

Goldin, B. and S. Gorbach, 1980. Effect of Lactobacillus acidophilus dietary supplements on 1,2dimethylhydrazine dihydrochloride-induced intestinal cancer in rats. J. Natl. Cancer Inst., 64: 263-265.

Haghighi, H.R., J. Gong, C.K. Gyles, M.A. Hayes and H. Zhou et al., 2006. Probiotics stimulate production of natural antibodies in chickens. Clin. Vaccine Immunol., 13: 975-980.

Havenaar, R., B.T. Brink and J.H.J. Huis in't Veld, 1992. Selection of Strains for Probiotic Use. In: Probiotics: The Scientific Basis, Fuller, R. (Ed.). Chapman and Hall, London, pp: 209-224.

Henry, R.J., 1974. Clinical Chemistry: Principles and Techniques. 2nd Edn., Harper and Row, New York.

Hong, H.A., L.H. Duc and S.M. Cutting, 2005. The use of bacterial spore formers as probiotics. FEMS Microbiol. Rev., 29: 813-835.
Ignatova, M., V. Sredkova and V. Marasheva, 2009. Effect of dietary inclusion of probiotic on chickens performance and some blood indices. Biotech. Anim. Husb., 25: 1079-1085.

Isk, M., F. Ekimler, N. Ozen and M.Z. Frat, 2004. Effect of using probiotics on the growth performance and health of dairy calves. Truk-Veterinerlik VeHayvanclk-Derg., 28: 63-69.

Isolauri, E., M. Kaila, H. Mykkanen, W. Ling and S. Salminen 1994. Oral bacteriotherapy for viral gastroenteritidis. Dig. Dis. Sci., 39: 2595-2600.

Kimura, K., A. McCartney, M. McConnell and G. Tannock, 1997. Analysis of fecal populations of bifidobacteria and lactobacilli and investigation of the immunological response of their human host to the predominant strains. Applied Environ. Microbiol., 63: 3394-3398.

Krehbiel, C.R., S.R. Rust, G. Zhangand and S.E. Gilliland, 2003. Bacterial direct fed microbial in ruminant diets: Performance response and mode of action. J. Anim. Sci., 81: E120-E132.

Kyriakis, S.C., V.K. Tsiloyiannis, J. Vlemmas, K. Sarris, A.C. Tsinas, C. Alexopoulos and L. Jansegers, 1999. The effect of probiotic LSP 122 on control of post-weaning diarrhea syndrome of piglets. Res. Vet. Sci., 67: 223-228.

La Ragione, R.M., G. Casula, S.M. Cutting and M.J. Woodward, 2001. I>Bacillus subtilis spores competitively exclude Escherichia coli O78:K80 in poultry. Vet. Microbiol., 79: 133-142.

Liong, M.T. and N.P. Shah, 2005. Acid and bile tolerance and cholesterol removal ability of Lactobacillus strains. J. Dairy Sci., 88: 55-66.

Majamaa, H., E. Isolauri, M. Salexin and T. Vesikari, 1995. Lactic acid bacteria in the treatment of acute rotavirus gastroenteritis. J. Pediatr. Gastroenterol. Nutr., 20: 333-338.

Mohan, J.C., R. Arora and M. Khalilullah, 1990. Short term hypolipidemic effects of lactobacillus sporogenes therapy in patients with primary dyslipidemias. Indian Heart J., 42: 361-364.

NAHMS, 2007. Dairy 2007, part 1: reference of dairy cattle health and management practices in the united states, 2007. USDA:APHIS:VS:CEAH, National Animal Health Monitoring System. Fort Collins, CO \#N480.1007.

Perdigon, G., C. Maldonado-Galdeano, J.C. Valdez and M. Medici, 2002. Interaction of lactic acid bacteria with the gut immune system. Eur. J. Clin. Nutr., 56: $821-826$. 
Perdigon, G., E. Vintini, S. Alvarez M. Medina and M. Medici, 1999. Study of the possible mechanisms involved in the mucosal immune system activation by lactic acid bacteria. J. Dairy Sci., 82: 1108-1114.

Rahimi, S. and A. Khaksefidi, 2006. A comparison between the effect of a probiotic (Bioplus 2B) and an antibiotic (virginiamycin) on the performance of broiler chickens under heat stress condition. Iranian J. Vet. Res., 7: 23-28.

Rodkey, F.L., 1965. Direct spectrophotometric determination of albumin in human serum. Clin. Chem., 11: 478-487.

SAS, 2000. Statistics, SAS User's Guide. SAS Institute Inc., Cary, NC, USA.

Salma, U., A.G. Miah, M. Nishimura and H. Tsujii, 2007. Effect of dietary Rhodobacter capsulatus on cholesterol concentration and fatty acid composition in broiler meat. Poult. Sci., 86: 1920-1926.
Sayed, A.S., 2003. Studies on the influence of pronifer as a probiotics on the clinical, hematological and biochemical status of the goat's kids. Assiut. Vet. Med. J., 99: 131-143.

Timmerman, H.M., L. Mulder, H. Everts, D.C. van Espen and E. van der Wal et al., 2005. Health and growth of veal calves fed milk medium replacers with or without probiotics. J. Dairy Sci., 88: 2154-2165.

Vasiljevic, T. and N.P. Shah, 2008. Probiotics-from Metchnikoff to bioactive. Int. Dairy J., 18: 714-728.

Wright, A.K., R. Giger, T.M. Arnold and E.D. Janzen, 1995. An episode of diarrhea in calves of a wellmanaged dairy herd. Can. Vet. J., 36: 36-38.

Zacconi, C., V. Bottazzi, A. Rebechi, E. Bosi, P.G. Sarra and L. Tagliaferi, 1992. Serum cholesterol level in axenic mice colonized with Enterococcus faecium and Lactobacillus acidophilus. Microbiologica, 15: 413-418. 